DOI: $10.4274 /$ tpa.486

\title{
A case of familial renal glucosuria with hipercalciuria and selective argininuria
}

\section{To the Editor,}

Primary renal glucosuria is a disease where glucose is significantly high in urine in conditions where the blood glucose level is normal. The prevelance of this condition which is also named non-diabetic glucosuria ranges between $0.16 \%$ and $0.29 \%$ (1). Continuous glucosuria (mellituria) is typical for the disease for which the diagnostic criteria were determined by Marble in 1947 for the first time (2). In this disease, the defect is only related with glucose excretion in urine. There is no abnormality in urinary excretion of other carbohydrates. Although excessive urinary glucose excretion is present, polyuria and polydipsia are not observed. There is no defect in usage and storage of glucose. The degree of glucosuria is independent of diet with a high proportion. The diagnosis is generally made in the second and third decade (3). Here, a child with familial renal glucosuria associated with argininuria and hypercalciuria is presented.

Glucosuria (++++) was found in the regular dipstick test performed in a 9-year-old male patient who presented to our outpatient clinic because of short stature. The other urinary variables were found to be normal. Physical examination revealed the following: weight: $27 \mathrm{~kg}(25 . \mathrm{p})$, height 132 $\mathrm{cm}$ (25.p), arterial blood pressure: $100 / 50 \mathrm{mmHg}$. The blood glucose level measured simultaneously was found to be $78 \mathrm{mg} / \mathrm{dL}$. The hematological and biochemical tests and hormone tests were found to be normal. Fasting blood glucose was found to be $69 \mathrm{mg} / \mathrm{dL}, \mathrm{HbA} 1 \mathrm{c}$ was found to be $4.1 \%$, insulin was found to be $13.21 \mu \mathrm{lU} / \mathrm{mL}$, C peptid was found to be $1.2 \mu \mathrm{g} / \mathrm{L}$, serum $25(\mathrm{OH})$ Vit D3 and parathormon levels were found to be normal. Glucosuria $(++++)$ was found again in the repeated fasting urinary test. This reflects a urinary glucose excretion above $1000 \mathrm{mg} /$ $\mathrm{dL}$. A diagnosis of benign renal glucosuria was made in the child whose 50 -gram oral glucose tolerance test was found to be normal. The glucose level in a 24-hour urine sample was found to be $17 \mathrm{~g} / \mathrm{L}$. The child had no polyuria or polydipsia. The spot $\mathrm{Ca} / \mathrm{Cr}$ ratio was found to be high. The patient who had hypercalciuria was the oldest child of a non-consanguineous family with three children. A familial history of intensive urolithiasis was present. 24-hour urinary calcium was found to be $7.2 \mathrm{mg} / \mathrm{kg} /$ day $(\mathrm{N}<4 \mathrm{mg} / \mathrm{kg} / \mathrm{day})$. Blood gases were found to be normal. Selective argininuria was found in urinary amino acid screening. The blood amino acid screening was found to be normal. The $\mathrm{Ca} /$ $\mathrm{Cr}$ ratio in spot urine measured for three consecutive days was found to be $0.31-20.28-0.36 \mathrm{mg} / \mathrm{mg}$ ( normal $<0.2 \mathrm{mg}$ / $\mathrm{mg}$ ). Renal ultrasonography revealed no pathology.

When the other two siblings and parents of the patient were screened, glucosuria (++++) was found in the brother and mother. The blood glucose, HbA1c, insulin, C-peptide levels and oral glucose tolerance test were found to be normal in the mother and brother. No health problem was observed in the mother except for borderline obesity. There was no familial history of renal disease or diabetes, but a familial history of urolithiasis was present. The patient who has been followed up in our outpatient clinic has no pathological finding except for glucosuria and idiopathic hypercalciuria. His height and weight is between the 25th and $50^{\text {th }}$ percentile.

Carrier proteins are involved in intracellular and extracellular transportation of glucose. Different diseases occur as a result of gene mutations in these glucosecarrier proteins named sodium-glucose transporter type 1 (SGLT1), sodium-glucose transporter type2 (SGLT2), glucose transporter1 (GLUT1) and glucose transporter 2 (GLUT2). Glucose-galactose malabsorption occurs as a result of gene mutation in sodium-glucose transporter type 1, familial renal glucosuria occurs as a result of gene mutation in SGLT2 and Fankoni-Bickel syndrome occurs as a result of gene mutation in GLUT2 (4). In familial renal 
glucosuria, primary transportation defect is in the sodiumglucose traype 2 (SGLT2) protein in the apical membrane S1 segment in the proximal renal tubular cells. Sodiumglucose transporter type 2 is found in liver cells, renal epithelial cells, pancreatic beta cells and intestinal basal membrane (5). As a result of mutations in the SLC5A2 gene coding sodium-glucose transporter type 2 protein, renal glucosuria ranging from mild glucosuria $\left(<10 \mathrm{~g} / 1.73 \mathrm{~m}^{2} /\right.$ day) to severe glucosuria ( $>10 \mathrm{~g} / 1.73 \mathrm{~m}^{2} /$ day) leading to varying degrees of glucose loss occur. In these patients, the average daily urinary glucose loss ranges between 20 $\mathrm{g}$ and $150 \mathrm{~g}$ (6). In our patient, the glucose level was found to be $17 \mathrm{~g} / \mathrm{L}$ in 24 -hour urine.

Although renal glucosuria is a benign condition, it may lead to hypovolemia, hypoglycemia, polyuria, enuresis, mild or moderate growth retardation and retardation in pubertal maturation, though rarely. In severe familial renal glucosuria cases, episodic water loss and ketosis may be observed especially during pregnancy (7). In these patients, predisposition to autoimmune diseases and recurrent urinary tract infections is increased (8). Selective amino aciduria has also been reported in cases of renal glucosuria. Cases with increased urinary excretion of aspartic acid, glutamic acid, cytrulline, alanine, arginine and taurine have been reported. In the follow-up of these patients, selective amino aciduria was not observed to lead to any clinical condition (9). The blood amino acid values were found to be normal in our patient who was found to have selective argininuria.

Patients with glucosuria should primarily be considered as diabetes mellitus and investigations should be started. Differential diagnosis with diabetes mellitus can be easily made with simultaneous serum glucose level, morning fasting blood glucose and urinalysis, oral glucose tolerance test and glycolysated hemoglobin level. When we found urinary glucose to be $(++++)$ in our patient, the blood glucose level measured urgently was found to be within normal limits. Since urinary dipstick tests used in regular biochemical laboratories are performed using glucose oxidase/peroxidase reaction, they are specific only for glucose. They do not show the other urinary sugars. Since hypercalciuria was present in our patient whose $\mathrm{HbA1c}$ and oral glucose tolerance test were found to be normal, urinary electrolytes and amino acid levels were measured to exclude other renal tubulopathies. Differential diagnosis with Fankoni-Bickel syndrome which leads to generalized amino aciduria, hypercalciuria, hyperphosphaturia, bicarbonaturia, polyuria, glucosuria, growth retardation, rachitis and renal tubular acidosis was made. There was no increased electrolyte excretion except for hypercalciuria in the patient who had normal blood gases.

Benign renal glucosuria is a self-limiting disease which is mostly asymptomatic and has a good prognosis in which medical treatment or diet limitation is not required. Differential diagnosis should be made with diabetes mellitus and other renal tubular diseases. As the age advances, glucosuria decreases due to decreased glomerular filtration related with atherosclerosis, but it is a life-long condition, though it does not lead to renal dysfunction. It is recommended that growth and development in these children be followed up yearly and they should not stay in a fasting state.

\section{Aysel Vehapoğlu Türkmen1, Mustafa Atilla Nursoy², Serdar Türkmen1, Mehmet Yazıcı1 \\ 1/stanbul Education and Research Hospital, Division of Pediatrics, Istanbul, Turkey \\ 2Bezmialem Foundation University, Department of Pediatrics, Istanbul,}

Turkey

\section{References}

1. Santer R, Calado J. Familial renal glucosuria and SGLT2: from a mendelian trait to a therapeutic target. Clin J Am Soc Nephrol 2010; 5: 133-141.

2. Marble A. Incidence of glycosuria and diabetes. Med Clin N Am 1947; 31: 313.

3. Wilgen $\mathrm{U}, \mathrm{Cobb} \mathrm{H}$. An unusual cause of glycosuria in a 5-year -old child. SAJCH 2008; 2: 134-135.

4. Calado J, Santer R, Rueff J. Effect of kidney disease on glucose handling (including genetic defects). Kidney Int Suppl 2011: S713. PMID: 21358700.

5. Lee $\mathrm{H}$, Han $\mathrm{KH}$, Park HW, Shin JI, Kim CJ. Familial rena glucosuria: a clinicogenetic study of 23 additional cases. Pediatr Nephrol 2012; 27:1091-1095.

6. Calado J, Sznajer Y, Metzger D, Rita A, Twenty-one additional cases of familial renal glucosuria: Absence of genetic heterogeneity, high prevalence of private mutations and further evidence of volume depletion. Nephrol Dial Transplant 2008; 23: 3874-3879.

7. Wright EM, Hirayama BA, Loo DF Active sugar transport in health and disease. J Intern Med 2007; 261: 32-43.

8. De Marchi S, Cecchin E, Basile A, et al. Is renal glycosuria a benign condition? Proc Eur Dial Transplant Assoc 1983; 20: 68185.

9. Sankarasubbaiyan S, Cooper C, Heilig CW. Identification of a novel form of renal glucosuria with overexcretion of arginine, carnosine, and taurine. Am J Kidney Dis 2001;37: 1039-1043. 